\title{
Influencing factors analysis of tensile properties of wool yarns with different proportions of polyamide blend
}

\section{REZUMAT - ABSTRACT}

Analiza factorilor care influențează proprietățile de rezistență la tracțiune a firelor de lână în amestec cu poliamida, în diferite proporții

Această lucrare prezintă o analiză comparativă a trei loturi de fire din lână cu diferite densitati de lungime, torsiuni și compoziții privind modul în care aceste caracteristici influențează proprietățile de rezistență la tracțiune a firelor. Au fost efectuate teste de rezistență la tracțiune, determinându-se valorile pentru următoarele caracteristici ale rezistenței la tractiune: forța de rupere, alungirea la rupere, tenacitatea și ruperea mecanică și au fost realizate diagramele eferente. Rezistența la rupere și alungirea la rupere - aceste diagrame prezintă distribuirea de secțiuni slabe de-a lungul firului testat. Pentru a realiza această analiză a fost utilizat echipamentul USTER® TENSOJET 4. Principalele concluzii ale acestei analize sunt următoarele: forța de rupere a firelor este determinată în principal de valoarea densității de lungime, procentul de poliamidă și valoarea torsiunii, iar alungirea la rupere este în primul rând influențată de procentul de poliamidă din compoziția firelor și apoi de gradul de torsiune a firelor, cele mai dure fire fiind cele cu cea mai mică finețe; ruperea mecanică la întinderea firelor depinde în principal de procentul de poliamidă din compoziția firelor, de finețea firelor și în final de gradul de torsiune al acestora.

Cuvinte-cheie: alungirea la rupere, finețe, poliamidă, forța de rupere, torsiune, fire

\section{Influencing factors analysis of tensile properties of wool yarns with different proportions of polyamide blend}

This paper presents a comparative analysis of three batches of wool yarns with different fineness, twists and compositions and the way in which these characteristics influence the tensile properties of the yarns. We performed the tensile strength tests and the values for the following tensile characteristics were determined: breaking force, elongation at break, tenacity and the mechanical breaking work and were made the diagrams. Stroke for strength and elongation at break - the diagrams give us an idea on the distribution of weak sections along the yarn tested. In order to make this analysis we used the machine USTER® TENSOJET 4. The main conclusions drawn from this analysis are following: the breaking force of the yarns is mainly determined by the value of length density and only after that by the percentage of polyamide and the twisting value, elongation at break is primarily influenced by the percentage of polyamide from the yarns composition and only then by the yarns twisting degree, the toughest yarns are the ones with the smallest fineness, the mechanical work created when stretching the yarns depends mainly by the percentage of polyamide from the yarns composition, by the yarns fineness and only then by their twisting.

Keywords: elongation at break, fineness, polyamide, breaking force, twisting, yarns

\section{INTRODUCTION}

The yarns, in all their forms, are products that are sold thus they are in direct contact with the market economy. In order to meet the requirements imposed by this market, the yarns should comply from a qualitative point of view and this depends both on the technology of obtaining them and also on the way the yarns behave during processing. In the present competitive age, quality of the all kinds of the textile product is the most desirable factor at purchase counter for the consumer [1].

The quality of the yarns seen as an objective of increasing the profit represents the consequence of correlating the characteristics of the yarns with the technology of their processing and their structure. The yarns breakage is caused by the unfavourable equilibrium between tensile strength and the yarns resistance which are variable during the technological process of production and processing and these breakages are produced only when the tensile strength exceeds its resistance. That is why the tensile properties of the yarns are accepted as one of the most important parameters for the assessment of yarn quality. Tensile properties contribute to the performance of post spinning operations; warping, weaving and knitting, hence their accurate technical evaluations very important in industrial applications [2].

Yarn quality is an essential concept defined by customer which requests the satisfaction of several properties simultaneously [3]. Among the decisive features for estimating the yarns usage value are: fineness, twisting, tensile strength, tensile elongation, the non-uniformity. Twisting the yarns is done in order to produce them and consequently to increase their tensile strength [4]. A fairly high degree of twist produces strong yarn; a low twist produces softer, more lustrous yarn; and a very tight twist produces crepe yarn [5]. 
Frequently used to assess the quality and value of using textile products, the tensile strength shows their ability to take over the axial efforts during products exploitation [6]. Tensile strength of yarns is influenced by characteristics by the raw material (length, length density and tensile strength of yarn components) and the level of twisting and it is calculated using the following indexes: breaking force, specific resistance, tenacity, the mechanical breaking work and tear length [7].

A physical-mechanical characteristic closely correlated with breaking force is the elongation at break of textile yarns [8]. During tensile stress of textile products they tend to elongate with a size dependent on the amount of effort applied and also on their own characteristics. After suppressing the tensile force we notice the tendency of the product to get back to initial length [9]. For the textile processing it is important that the fibres and yarns to be solicited with forces that would produce only elastic elongation, thus keeping the proportionality between effort and deformation, to spare their tensile properties [10].

Textile products in general have a certain non-uniformity of their own characteristics, which is manifested by the variation of specific parameters such as: the number of yarns in the cross section, the length density, tensile strength, etc. [11]. The unevenness of the textile products characteristics on the one hand is caused by the unevenness of the constituent yarns and on the other the imperfections of the technological processes of their processing. The unevenness of the yarns greatly influences their processing and the products appearance made of them [12].

Another influential factor of products quality is the yarn breakage (both during technological process of production and in their processing), breakages which are determined by the unfavourable balance of tension and yarns resistance [13]. This is the main reason why in this paper we are doing a comparative study of tensile properties for three batches of wool yarn mixed with polyamide in different percentages of different fineness and different twists.

\section{MATERIALS AND METHODS}

The tensile properties for the 3 batches of yarns were studied, performing tensile strength tests on 10 samples from each yarn batch with the help of the device USTER® TENSOJET 4. The three yarns batches have the following features:

- Batch I is formed $80 \%$ of woollen yarns mixed with $20 \%$ polyamide, with length density of Ttex $=31.25$ and twist of $412 \mathrm{spins} / \mathrm{m}$.

- Batch II is formed $90 \%$ of woollen yarns mixed with $10 \%$ polyamide, with length density of Ttex $=33.33$ and twist of $412 \mathrm{spins} / \mathrm{m}$.

- Batch III is formed $80 \%$ of woollen yarns mixed with $20 \%$ polyamide, with length density of Ttex $=25$ and twist of $498 \mathrm{spins} / \mathrm{m}$.

\section{RESULTS AND DISCUTION}

After performing these tensile strength tests the values for the following tensile characteristics were determined: breaking force, elongation at break, tenacity and the mechanical breaking work and were made the diagrams Stroke for strength and elongation at break - the diagrams give us an idea on the distribution of weak sections along the yarn tested. For each yarn batch were determined the minimum, maximum, average values and the variation coefficient for all 4 analysed tensile characteristics. The values obtained are presented in the following centralized tables (1-4).

\begin{tabular}{|l|c|c|c|}
\hline B-Force (cN) & Batch I & Batch II & Batch III \\
\hline Mean & 259,6 & 269,0 & 224,7 \\
\hline Cv & 12,4 & 12,5 & 12,8 \\
\hline Min & 75,26 & 111,1 & 119,5 \\
\hline Max & 385,9 & 391,8 & 357,1 \\
\hline
\end{tabular}

Table 2

\begin{tabular}{|l|c|c|c|}
\hline \multicolumn{4}{|c|}{ ELONGATION AT BREAK, FOR THREE YARNS } \\
BATCHES \\
\hline Elongation (\%) & Batch I & Batch II & Batch III \\
\hline Mean & 14,93 & 8,69 & 13,11 \\
\hline Cv & 27,3 & 32,3 & 31,4 \\
\hline Min & 2,36 & 1,66 & 3,36 \\
\hline Max & 27,03 & 21,58 & 25,85 \\
\hline
\end{tabular}

Table 3

\begin{tabular}{|l|c|c|c|}
\hline \multicolumn{4}{|c|}{$\begin{array}{c}\text { TMECHANICAL BREAKING WORK, FOR THREE } \\
\text { YARNS BATCHES }\end{array}$} \\
\hline Tenacity (cN/Tex) & Batch I & Batch II & Batch III \\
\hline Mean & 8,31 & 8,07 & 8,99 \\
\hline Cv & 12,4 & 12,5 & 12,8 \\
\hline Min & 2,41 & 3,33 & 4,78 \\
\hline Max & 12,35 & 11,76 & 14,29 \\
\hline
\end{tabular}

Table 4

\begin{tabular}{|l|c|c|c|}
\hline \multicolumn{4}{|c|}{ ELONGATION AT BREAK, FOR THREE YARNS } \\
BATCHES \\
\hline B-Work (cN*cm) & Batch I & Batch II & Batch III \\
\hline Mean & 1554 & 885,1 & 1171 \\
\hline Cv & 36,9 & 46,2 & 42,2 \\
\hline Min & 78,67 & 64,44 & 151,7 \\
\hline Max & 3483 & 2785 & 2918 \\
\hline
\end{tabular}

In order to get a more accurate picture regarding the distribution of weak sections along the tested yarns, there were also made the Stroke diagrams for breaking force and elongation at break. Figures 1 and 2 show these diagrams obtained for yarn batch I. 


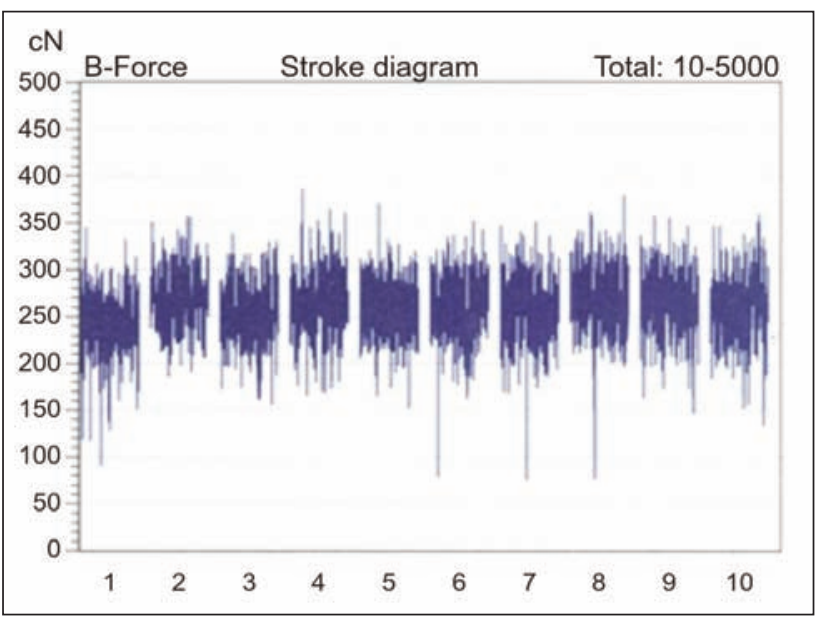

Fig. 1. Variation diagram for breaking force of yarns from batch I

Breaking force of the first batch of yarns varies between 75.26 and $385.9 \mathrm{cN}$ and has a breaking force average value for this type of yarns of $259.6 \mathrm{cN}$. For batch II the breaking force average value is $269 \mathrm{cN}$, minimum and maximum limits being 111.1 and $391.8 \mathrm{cN}$, respectively. It was found that the yarns made of $80 \%$ wool $+20 \%$ polyamide, and with tex fineness 25 have the lowest breaking force, their average value being $224.7 \mathrm{cN}$.

Comparing the fibrous composition, twist and fineness of the yarns in the three batches the conclusions were the following:

- The thicker yarns in batch II have a better resistance compared to yarns in batch I, although their polyamide synthetic component is of only $10 \%$ compared to $20 \%$ polyamide of yarns in batch I, a component that should improve these properties.

- The yarns in batch II have better resistance compared to the yarns in batch III although the proportion of polyamide is half compared to that of the yarns in batch III and moreover the yarns in batch II have a smaller twist than the ones in batch III.

- The yarns in batches I and III which have the same polyamide percentage in their composition but the yarns twist is different (is higher in batch III compared to that of the yarns in batch I) but have a different breaking force, it is higher for the yarns in batch I because they are thicker than those in batch III.

From the facts presented above we can conclude that the breaking force of the yarns is mainly determined by the value of length density and only then by the polyamide percentage and twist value (which is known to improve the yarns resistance).

Regarding the elongation at break - as it was expected, the highest values were recorded in the batches in whose component the polyamide percentage is higher - i.e. the batches I and III. Even if the fibrous composition of the two groups is identical we notice that different values of elongation at break were

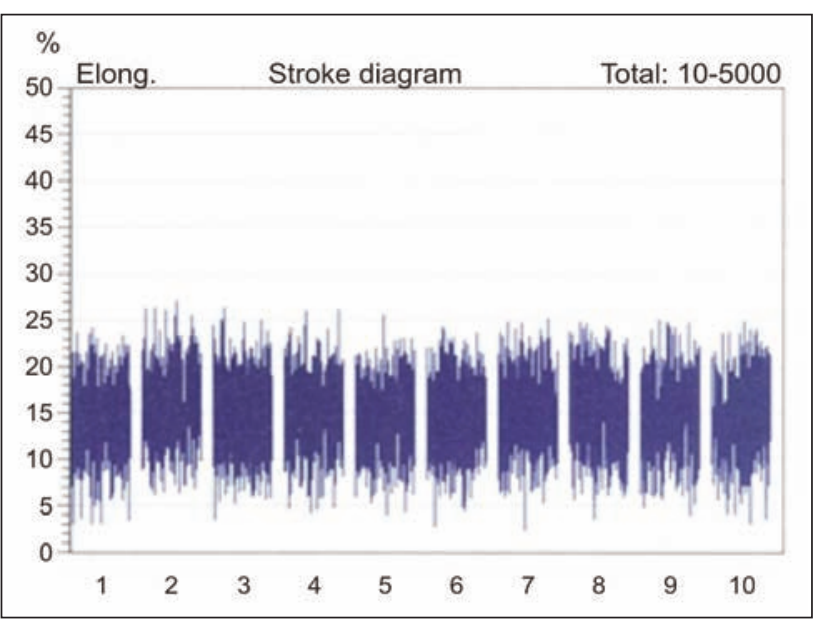

Fig. 2. Variation diagram for elongation at break for yarns from batch I

obtained - i.e. $14.93 \%$ (batch I) and $13.11 \%$ respectively (batch II) the main difference being given by their different degree of twisting (much higher in batch III).

Comparing the three yarns batches tenacity we noticed that even though the breaking force is the lowest for yarns in batch III, their tenacity has the highest value since its value is inversely proportional to the yarns finesse.

By comparing the values obtained for the mechanical work created when stretching the yarns in the three batches we noticed that:

- The highest values - in 1554 and 1171 respectively $\mathrm{cN}^{*} \mathrm{~cm}-$ are recorded in the batches I and III, batches which are composed of the highest percentage of synthetic fibre

- The mechanical work created when stretching the yarns in batch II register the lowest value 885.1 $\mathrm{CN}^{*} \mathrm{Cm}$ - is consistent with the percentage of synthetic fibre.

- The yarns in batch I even though have a lower twist than those in batch III, they tear hardly and in order to be broken a higher mechanical work must be created due to the fact that their thickness is greater.

\section{CONCLUSIONS}

As a result of these comparative analyses of yarns tensile properties in the 3 batches the following conclusions are drawn:

- The breaking force of yarns is mainly determined by the value of length density and only then by the percentage of polyamide and twist value (which is known to improve the yarns resistance);

- Elongation at break - is primarily influenced by the percentage of polyamide from the yarns composition (the greater this is, the higher the value of elongation at break) and only then by the degree of yarns twisting (the higher the twisting the lower the elongation at break); 
- The highest tenacity is obtained by the yarns with the lowest fineness;

- The mechanical work created when stretching the yarns depends mainly by the percentage of polyamide from the yarns composition (the higher the percentage the bigger the mechanical work value). Yarn fineness is the next factor influencing the mechanical work necessary for yarns breakage and only then the yarns twisting.

The results of these analyses are successfully applied in textile industry, weaving mills and knitwear, where choosing the yarns with high tensile strength is highly important in obtaining high quality products.

\section{BIBLIOGRAPHY}

[1] Kotb, N. A. Predicting yarn quality performance based on fibers types and yarn structure, In: Life Science J 9(3), (2012), pp. 1009-1015.

[2] Das, B. R., Ishtiaque, S. M. and Rengasamy, R. S. Static and dynamic tensile behaviour of spun yarns: A critical review, In: Breaking force, for three yarns batches Research Journal of Textile \& Apparel, Vol. 15 Issue 4, (Nov 2011), pp. 70-83.

[3] Souid, H. \& Cheikhrouhou, M. Slup Yarn quality optimization by using desirability function and neural networks, In: Journal of Applied Science 11(17), (2011), pp. 3204-3208.

[4] Gribincea, V. \& Bordeianu, L. Fibre textile - Proprietăţi generale, In: Editura Performantica, laşi, (2002).

[5] Neha Gupta, Analysis on the defects in yarn manufacturing process \& its prevention in textile industry, In: International Journal of Engineering Inventions, e-ISSN: 2278-7461, p-ISSN: 2319-6491, Volume 2, Issue 7, (2013), pp. 45-67.

[6] Abhijit, M. Assessment of tensile properties of cotton yams, In: Indian Journal of Fibre\&Textile Research, Vol. 26, (2001), pp. 354-357.

[7] Avram, M., Avram, D. and Bahu, L. Structura firelor, Editura Gh. Asachi, Iaşi, 2002.

[8] Cioară, I. \& Onofrei, E. Inginerie generală în textile-pielărie. Îndrumar de laborator, Editura Performantica, laşi, 2006.

[9] Cioară, I. \& Onofrei, E. Inginerie generală în textile-pielărie, Editura Performantica, laşi, 2007.

[10] Oana, D., Suteu, M., and Oana, I. The study of irregularity elongation of yarns of wool in mixture with silk using the Uster® Tensojet 4 Machine, In: Annals of the University of Oradea, Fascicle of Textiles-Leatherwork, Oradea, vol. XVI, nr. 2, (2015), pp. 51-56.

[11] Avram, M. \& Avram, D. Structura și proprietățile firelor, Editura CERMI, laşi, 1998.

[12] Antoniu, Gh. \& Arnăutu, I. Fibre textile. Aplicaţii, Vol. 2, Editura Dosoftei, laşi, 2002.

[13] Oana, D., Oana, I. P., Suteu, M. The thinness degree study of wool yarns of different origins using the Uster machine/Studiul gradului de subtirime a firelor de lâna de provenienta diferita cu ajutorul aparatului Uster. In: Industria Textila, 66.6: 329, 2015.

\section{Authors: \\ Lecturer PAVEL OANA IOAN \\ Lecturer DORINA OANA \\ Lecturer SIMONA TRIPA}

Department of Engineering and Industrial Management in Textiles and Leatherwork University of Oradea, Ro- 410041, Oradea, str. Universitatii nr. 1, Oradea, Romania e-mail: oanaioanpavel@yahoo.com, tripasimona@yahoo.com

Corresponding author:

IOAN PAVEL OANA

e-mail: oanaioanpavel@yahoo.com 